\title{
Market-Driven Solutions to Economic, Environmental, and Social Issues Related to Water Management in the Western USA
}

\author{
Jordan A. Clayton
}

Department of Geosciences, Georgia State University, P.O. Box 4105, Atlanta, GA 30302, USA; E-Mail: jclayton@gsu.edu; Tel.: +1-404-413-5791

Received: 15 September 2009; in revised form: 5 October 2009 / Accepted: 8 October 2009 / Published: 9 October 2009

\begin{abstract}
Water management issues continue to plague the western United States, including rapid population growth, degraded aquatic ecosystems, unfulfilled claims to American Indian users, the threat of global warming, an economic recession, and many other issues. This essay outlines some advantages of market-driven reforms to the management of water resources in the western USA. Historical and contemporary western water resource issues are examined from economic, environmental, and social viewpoints. In all such contexts, it is argued that regulated water markets provide flexible and just solutions to western water dilemmas, and reallocations may provide much-needed additional water supply.
\end{abstract}

Keywords: water markets; USA West; prior appropriation; transfers

\section{Introduction}

It is increasingly recognized that international competition for water resources may lead to conflict [1,2], particularly where resources are diminishing. A microcosm of the international situation occurs in the United States, where conflicts over water resources in eastern states have become more numerous in recent decades [3,4]; in western states water disputes have been more commonplace [5-8]. It was recognized early on that the arid conditions that affect much of the western USA would limit widespread development [9] and precluded western regions from adopting the riparian water law 
system used in eastern states. However, the strict seniority principle that was adopted to govern water law in the West, the prior appropriation doctrine (described in detail below), remains problematic because it does not consider societal values of different market uses of water, sets up barriers to water transfers, ignores the legal owners of the water (the federal and state governments), ignores the nonmarket players (such as environmental and aesthetic concerns), and disadvantages or poorly represents impoverished communities [10]. It is suggested herein that market-driven solutions to these problems may be incorporated into the existing appropriation scheme and may be best-suited to resolve difficult and complex western water allocation issues.

\section{Economics}

Many authors have claimed that, rather than water being scarce in western states, water allocation is inefficient [11-14]. As with the development of many resources in the American west, the economic allocation system for water is rooted in a history of extraction and expansion. The prior appropriation doctrine has its roots in the mining of gold in both California and Colorado. Miners anxious to claim ownership to a given gold location used the system of "first in time, first in right", meaning that seniority ruled and that the right is indefinite in time but may be lost from inactivity [15]. Several factors combined to cause these mining communities to adopt the prior appropriation theme for water as well. First, the water was needed far from the streams in which it flowed in order to extract the gold. The density of surface water in the west was far inferior to that of the east, where the riparian doctrine rules water policy, so actual riparians were fewer in number and would have had the capability to dominate water use. Additionally, the vast majority of lands in the west were publicly, not privately, owned. This lack of land ownership precluded the ability of a water user to be a legitimate riparian and necessitated an alternate system. Miners therefore adopted the prior appropriation system for water use in California, thereby formalizing the seniority system for water allocation.

In 1853, the California Supreme Court ruled in Irwin v. Philips that the senior could divert water even to the detriment of a downstream riparian. In his decision, Justice Heydenfeldt invoked the logic that the prior appropriation system was already being used and working, and that "costly artificial works" had been constructed in the context of this seniority-based system. Later, the Colorado Supreme Court case of Coffin v. Left Hand Ditch Company (1882) confirmed that the practice of prior appropriation would adhere to the strict seniority system in that state and elsewhere.

Throughout the West, in a region with insecure water availability, early farmers and other settlers recognized the security of the prior appropriation scheme and adopted it. Land developers knew that land far-removed from streams would be worthless under riparian ideals, so they backed the appropriation system to promote development and profits. Finally, it was recognized by western states that the prior appropriation system allowed the states to control water allocation, even where the land was federally-owned [16].

The prior appropriation system can be summarized as follows: the user that first demonstrates intent to put the water to a beneficial use (traditionally through a diversion) claims priority to the necessary amount of water. Beneficial use is granted for those uses of water requiring a diversion, such as domestic, agricultural, mining, industrial, and municipal water withdrawals. In some cases in-stream use have been considered beneficial; historically these have been limited to hydropower and 
navigation, though in recent decades this has expanded to sometimes also include recreation, aesthetics, and ecosystem protection. The claim is specified to a given diversion amount and adjudicated through a hierarchical enforcement system of ditch runners to state engineers [15].

Not considered, however, by the seniority system are the market values of a given activity, such as economic efficiency. The only conditions to absolute claims to water in the west by a senior are a prohibition against excessive waste and a requirement for continual use. A number of authors [e.g. $17,18]$ claim that this is an outdated system. In general, there have been no initiatives to grant priority to certain uses over others- the system simply awards those who claimed the water first. Moreover, under the prior appropriation system, and unlike most other resources, water is claimed as permanent property once it is put to use- without payment to state or federal governments $[16,19,20]$. Today there is considerable inertia in the current system as those who have benefited historically (large-scale private agricultural and industrial water interests, construction and labor organizations, western policymakers, etc.) seek to maintain the status quo [21,22]. Wilkinson [23] suggests that the power structure in western water affairs includes water development interests and state agencies, federal water development organizations (such as the U.S. Bureau of Reclamation and the U.S. Army Corps of Engineers), and key congressional members of related subcommittees that combine forces to maintain a system of outside funding (e.g. tax dollars) and internal control.

Increasingly, both economic and environmental reformers have been calling for relaxed restrictions on water transfers in order to move water use from inefficient to more efficient applications [24,20]. Davis [14] points out that water transfers from agricultural to urban uses moves the water from a system of heavy subsidies and low market prices to that of high willingness and ability to pay of urban water users. Agricultural water use (around 90 percent of the water used in the West) is often inefficient due to excessive runoff and seepage, evaporation, and transpiration from phreatophytes [23]. A transfer to urban uses, therefore, is likely to both reduce water waste and meet necessary demands [25]. Brajer and Martin [13] point out that, as with any resource priced below its value, excess demand is created by the low price of water (from governmental subsidies and a lack of leasing charges), thereby compounding the mentality that the resource is "scarce". They argue that the historical response to water shortage has been through continual supply development, and demand management, such as allocation reform and efficiency in use, have been largely ignored.

Because of the diverse needs for water as a resource, it is uniquely appropriate for redistribution through markets. As prices rise to meet actual costs of delivery and market values, use will decrease amongst inefficient sectors [13,19,20]. Also, a competitive water market would promote efficiency by reducing the differences in risk between senior and junior water users [11]. Seniors bear less risk because their investments in water use are less threatened by the temporal variability in water availability. Certainty to water availability is critical to development in the west. Insofar as the current system hampers the ability of users to transfer or loan water to higher economic uses, the current system does not provide adequate security for junior users.

Wescoat [26] points out that efficiency is also made difficult by the working definition of "beneficial use". In principle, the definition of beneficial use is based on the amount of water that is reasonable and appropriate (which ought to include local environmental factors). However, in practice, beneficial use is defined by the legal concept of injury, meaning that a use is efficient insofar as it does not injure downstream seniors through excessive waste. Interestingly, some recent signs indicate that 
the U.S. Department of the Interior is taking a more critical view of wasteful use of water in the West. For example, Imperial Irrigation District water users recently saw their allotment of water decrease by approximately 276,000 acre-feet- roughly the amount that the Interior Department declared they were wasting through their antiquated distribution systems [27].

Another problem arises from ambiguities in the definitions to water rights. For example, is the right a right to the amount of water diverted or actually consumed? According to Anderson and Leal [28], market incentives would arise to promote more efficient water use if these aspects of the market were more clearly defined, both for the potential seller and buyer in the market transfer. Others [22] claim that a lack of public review or modification process allows inefficiency to continue. Indeed there is evidence from some western states (e.g. Montana) that public review of water use can increase its efficient allocation [29,30].

A common thread to these problems is economic inefficiency. Economic inefficiencies arise because externalities (such as downstream users and recreational benefits) are ignored [31], and there is an unequal enforcement of existing allocation standards [28]. These inefficiencies may possibly be alleviated from a stricter adherence to beneficial use standards, public review, and long-term leasing (as opposed to permanent allotment) of water rights with possibilities for extensions at the end of the leasing period [22,32]. The more common solution proposed, however, is that of a relaxation of market transfer restrictions to allow the ready movement of water from less to more efficient and economically worthy applications. For example, farmers receiving water from U.S. Bureau of Reclamation projects might be allowed to sell at least a portion of that water for profit [33]. Water transfers tend to be rather costly, time-consuming, and legally complicated, a certain disincentive for many. A less-regulated, faster, market-driven water transfer system would benefit western economies and would likely reduce water use [20].

\section{Environment}

Given that the water law system in the USA West focuses exclusively on seniority, it tends to ignore water users that are not represented by the prior appropriation scheme, such as environmental uses of water. In many locations, degradation of aquatic ecosystems has resulted from an inadequate representation of water interests on the behalf of water flora and fauna, and a neglected need to preserve water quality in a system that address water quantity only. At times, disinterest in environmental needs has been explicit. By fully appropriating the river (and misinterpreting the longterm flow levels), the Colorado River Compact of 1922 and its subsequent reforms ignored the needs of fish species and aquatic ecosystems, and deliberately resisted addressing the salinity of water delivered to Mexico, instead focusing only on water quantity [7,18]. These issues were eventually addressed when the pumping of highly saline water into the river just north of the US-Mexico border coincided with reduced Colorado River flows from upstream due to the filling of Lake Powell, causing the water reaching Mexico to be extremely saline and essentially unusable. With few exceptions, such as the Sierra Club's fight against dams in the Hetch-Hetchy Valley and Echo Park, the environmental effects of water use in the west had not been addressed until the reforms of the 1960s and 70s. Since then, the Wild and Scenic Rivers Act (1968), Endangered Species Act (1973), National Environmental Policy Act (1970), the Clean Water Act (1972), and many other pieces of legislation have greatly 
hindered the continual development of water supply in the west and have increased public awareness and involvement in water-related decision-making [23]. The impacts of these acts of legislation have made it increasingly apparent that private water rights are not absolute, but rather are subject to state or federal authority [34]. Environmental protections are now increasingly afforded through in-stream flow programs, wetlands protections, and basin-of-origin protections. In the 1980s, environmental groups claimed victories as both Los Angeles and Denver were affected by regulations that limited potential impacts of water supply structures; reduced withdrawals were mandated for California's Mono Lake, and Denver was unable to construct the proposed Two Forks Dam- both cases cited ecological concerns [35].

As most of the environmental reforms have come at the federal level, an issue which continues to show up around environmental protection is that of state versus federal control. The 1982 U.S. Supreme Court case Sporhase v. Nebraska reminded western states of the federal power to regulate commerce, and in turn, require certain amounts of water to be delivered to downstream states. Moreover, the Federal government, not western states, has the ultimate control over all public resource ownership, including western water. These Federal rights to western water are often difficult to incorporate into the states' prior appropriation allocation systems because the exact appropriation amount may be poorly quantified, the uses of the water may not be considered beneficial according to state standards, the rights may be asserted at unknown dates, and the rights do not require continued use or due diligence [29]. Tarlock [36] states that deference to state water law systems, where it exists, is merely a matter of federal policy not to preempt state law and is not a waiver of congressional constitutional power. Still, the impression that states own the water that flows within their boundaries is pervasive- though such impressions are ultimately being proven incorrect by the enforcement of environmental legislation.

Specifically, environmental legislation and in-stream flow programs create de facto regulatory water rights [36]. Whereas environmental legislation rights are typically much stronger as they tend to sidestep the appropriation system completely (such as requiring flow levels needed to protect endangered species, irrespective of senior water users' demands), in-stream flows are generally incorporated into the seniority system. Thus, in-stream protections are generally weaker unless they are granted rather senior priority dates, such as with allocations to Indian Reservations and earlyestablished national parks. In-stream flows generated today by public or private organizations obtain contemporary priority dates and therefore generally serve to preserve the status quo, which in some cases is inadequate protection for aquatic ecosystems.

Some environmental advocates have suggested that free-market water transfers threaten environmental protections. The claim is that a strict market system would undermine environmental restrictions by allowing excessive water to be transferred from one location to another; this also would have social ramifications (see next section). Wescoat [37] describes a coalition of environmental, urban, and rural groups pitted against growing suburban water interests in a fight against water transfers from Colorado's west slope. Many fear that private capital interests will continue to dominate water use to the detriment of rural communities and ecosystems [21,37]. On the other hand, Colby [31] argues that in-stream flow rights incorporated into the water market can afford earlier priority dates, and thus greater protection, to environmental interests while at the same time moving water from inefficient to more efficient uses. As an example, the state of Oregon has enacted legislation that 
allows farmers to sell conserved water. This is encouraging and should become the norm in western states. Conserved water may also be added to the water allocation system by creating water banks wherein participating farmers could lease water for environmental purposes [33]. Thus, environmental goals may be obtained largely from market-driven forces, themselves rooted in a western economy increasingly centered on recreation and tourist dollars [31,38]. Recreation-based claims to water in western rivers (which concurrently benefit stream environments) typically seek maintenance of fairly minimal flow levels and have negligible consumptive uses [39]. Full acceptance of the recreation potential in western economies would therefore seem to promote the mutual goals of economic development and environmental protection. A greater incorporation of in-stream flow rights into the water rights market would certainly serve to meet these ends.

\section{Societies}

In addition to the recognition that some water must remain within streams to preserve aquatic communities, westerners are increasingly in favor of regulations that maintain that water should generally remain within the same watershed for the benefit of local societies. This is essentially a riparian-based idea applied to western water [10,30] insofar as the strict Colorado Doctrine application of the prior appropriation has, since Coffin v. Left Hand Ditch Company (1882), explicitly denied basin-of-origin protections [15]. Famous out-of-basin transfers, such as the diversion of surface waters draining Owens Valley in California to facilitate Los Angeles metropolitan area development [7,40], have heightened interests on behalf of the original basin's users to keep the water, and its economic security, in place.

Farmers tend to view water as their ultimate marketable commodity. The removal of substantial amounts of water from a given basin threatens rural communities- especially where small to mid-sized family farming operations predominate [12]. Key threats stem from a reduced ability for future water development within the community, loss of open space for urban expansion, loss of a critical mass within the farming community as grain, equipment, and other dealers and local banks go out of business, reduced interest in local welfare due to increased amounts of land owned by outside interests, and the influx of weeds from proximal retired farmlands [41]. Wescoat et al. [42] describe a loss of "community values" in addition to these "commodity values" that include emotional and symbolic value, participation and local control, and collective decision-making. Moreover, often ignored in water transfer economics or equity concerns are those who work on the retiring lands- they gain nothing from the transfer.

Some authors argue for increased public involvement in water transfers to protect rural interests [30]. Tarlock [10] cites a case in northern New Mexico where the "public interest" was used to keep a water transfer from threatening a local community on historical, cultural preservation grounds. A solution in this case might be to require that a substantial portion of profits gained from the transferred water be returned to the original basin [12] or that a portion of the basin-of-origin's right be preserved [24]. This would help alleviate the fact that, for subsistence and small farms, the price of water is somewhat inelastic insofar as that a minimum amount is required for production. Another potential solution would be to allow basins to recapture water that has been transferred after some allotted amount of time. However, the strongest protection of social equity that can be afforded to rural 
communities may come from increased efficiency in water use in those areas [17]. Efficient water use will reduce costs, augment the local economy, and strengthen water rights claims. Western states should seek to facilitate the move towards efficiency on these grounds and for their own economic security.

Equity is not limited to basin-of-origin water claims, however. A lengthy literature exists describing the history of neglect of American Indian reservation claims. Deloria [43] asserts that these issues remain unresolved because of the following paradox: full recognition of Indian rights has been a historical impossibility, and yet full denial is morally infeasible. The solution, according to [43], has been to narrow the rights as much as possible while concurrently stalling negotiations until such point whereupon water development costs become insurmountable. Whatever the reason, Indian reservation claims remain one of the biggest unresolved issues in western water management.

Reservation claims to western water stem from the U.S. Supreme Court ruling in Winters v. United States (1908). The case grew from a conflict along the Milk River in northern Montana between the Fort Belknap Indian Reservation, which was established within the basin in 1888, and downstream water users such as Henry Winters, who began legally diverting water around 1905 for agricultural purposes. Winters and other downstream users appropriated much of the water in the basin, leaving little remaining water for the upstream reservation to appropriate within the seniority system. Regardless, the reservation's occupants began diverting water for irrigation, thereby reducing flows to the downstream off-reservation users [39]. The Court ruled in favor of the reservation because it was decided that the federal government had intended to reserve water rights for reservation use when the reservation was first established. It had been explicit government policy to make the Indians pastoral and economically self-sufficient. According to Pisani [44], this met the goals of eliminating them as a security threat, reducing the cost of feeding them, and teaching the Indians about western virtues and civilization. The use of reservations was also favored because moving the Indians to marginal lands would free up more, and typically better, land for homesteaders [33]. Whatever the rationale, the Court deemed that the stated goal of making the Indians pastoral and economically self-sufficient implicitly required some water to be reserved for agricultural purposes on the reservation. Importantly, the date of the implicit water right equaled the date of the relevant treaty that set up the reservation. This ruling gave the Fort Belknap Indians an 1888 priority date, making them the seniors to the downstream users. Interestingly, in more recent times the Federal government has used the same logic to assert a reserved right to water on USA public lands (e.g. military bases, national parks, monuments, and forests, and wilderness areas), maintaining that a certain amount of water was implicitly granted to the given piece of land when it was established as federal property; this practice was upheld by the 1963 U.S. Supreme Court decision in Arizona v. California [39,34,15].

Suggested water management solutions [e.g. 45,46] all seem to agree that resolution of Indian reservation claims is of utmost importance but none really describe in detail how that may proceed. Until the reservation's economy is recognized as part of the larger state economy [43], the settlement of these claims and the equity issues involved seems unlikely. Equity may be greatly improved by allowing reservations to transfer water rights to downstream users, even if such users are in other states, thereby increasing the resource capital on the reservation, moving water to a higher economic value, and allowing Indians to turn paper claims to water to "wet claims". However, the legality of such transfers remains unclear $[33,44]$. 


\section{Concluding remarks}

Economic, social, and environmental problems related to the allocation of water in the western USA are presented above with a common thematic solution: relaxation of water transfers from a market perspective, while at the same time enacting public interest legislation to protect equity and environmental quality in basins-of-origin. Responsible water trading may be promoted by: (1) incorporation of public review; (2) simplification of water transfer protocols and legal systems to ease trading, reduce costs, and increase flexibility; (3) incorporating expiration dates for traded water; (4) the use of water banks- particularly for water trades across state lines; (5) requiring that a useable portion of the water remain associated with its previous use; and (6) including externalities in the pricing of water. Such changes are necessary in a system that is, at least legally, indifferent to all considerations except priority. Bates et al. [16] state: "Laws in other areas - civil rights, due process, torts, free speech- tend to reflect basic ideas of right and wrong. Not so in water law. Beyond the simple appeal of first-come, first-served, the prior appropriation doctrine is not tied to any widely held principles." The market solutions presented above allow for both the continuation of the prior appropriation system and the economic security of reform instead of revolution in policy decisionmaking, while also considering those elements of society and the environment that would otherwise be ignored in a strict seniority system. Water has been historically under-priced and under-valued by USA and global pricing [47-49,20]. As current allocation schemes may become increasingly challenged by changes in runoff timing and diminished overall flows related to global climate change [50-53], market-driven solutions afford much-need flexibility in the management of this precious resource [5456]. Model predictions of coincident population increases and future water shortages in the western USA underscore the need to embrace voluntary [57,58], socially-just [59], and institutionalized [60] water marketing schemes.

Arguments against water marketing include the potential for monopolization of resources [61] and wealth [62], the exclusion of non-market players (such as ecological resources) in water's economic valuation, resulting in potential environmental degradation [63], and the general sense that water is a public good and should not be subjected to economic forces [49,64]. Evidence from California [65] suggests that real estate development may be limited when water rights are transferred. Some rural areas of the West have passed regulation to reduce the transferability of water rights due, mainly, to concerns related to the long-term economic health of source regions of water trades and fears that the loss of agricultural productivity will lead to increased levels of unemployment and other social issues [66]. Popular accounts of local resistance to water transfers [7,67] generally depict such transactions negatively- particularly as related to the perceived loss of long-term economic viability in the source region and to market inequalities; some suggest that such inequities doom the viability of water markets as a solution to the water allocation dilemmas facing western states [68].

When adequately regulated, however, adapted to minimize trading obstacles [69], and adjusted according to regional constraints $[63,70]$, water (and other resource) trading has generally resulted in improved market stability and efficiency [71]. Case studies and empirical models of water management in the American West generally highlight the potential successes of equitable water markets [72-75]- particularly when coupled with sound oversight, conjunctive management of surface water and groundwater, and adequate basin-of-origin protections [76,77]. Negative social and 
hydrological impacts associated with water trades may be short-lived [69]. Aquatic ecosystems may benefit from water markets when in-stream rights are purchased to satisfy environmental regulations or societal interests [66,78]. Farmers in water-depleted regions may switch to low water demand crops or more efficient water-delivery methods [69]. While the complex water allocation issues facing the western USA may not solved from singular prescriptions [70], well-designed water markets may provide a useful means to efficiently and equitably distribute this important resource [79]; if so, evidence for increasing numbers of water trades in recent years [80] is encouraging.

\section{Acknowledgements}

This document was improved from helpful comments and suggestions from Douglas Kenney, John Pitlick, Robert Anderson, Nel Caine, James D. Smith, and four anonymous reviewers.

\section{References and Notes}

1. Gleick, P.H. Water and terrorism. In The World's water 2006-2007: the Biennial Report on Freshwater Resources (World's Water); Gleick, P., Cooley, H., Katz, D., Lee, E., Eds.; Island Press: Washington DC, USA; 2006; pp. 1-25.

2. Dinar, A.; Dinar, S.; McCaffrey, S.; McKinney, D. Bridges over water: Understanding transboundary water conflict, negotiation and cooperation. World Scientific Series on Energy and Resource Economics, v. 3; World Scientific Publishing Co.: New Jersey, USA, 2007; 468 p.

3. Barnett, C. Mirage: Florida and the vanishing water of the Eastern U.S; U. of Michigan Press: Ann Arbor, USA, 2007; 240 p.

4. Sheinin, A.G.; Keefe, B., 2009. Perdue warns of more water wars, calls for national policy. Atlanta Journal-Constitution, 29 July, 2009.

5. Marston, E. Western water made simple; Island Press: Covello, USA, 1987; 237 p.

6. Stegner, W.E. Beyond the 100th Meridian: John Wesley Powell and the 2nd opening of the West; Penguin Books: New York, USA, 1992; 438 p.

7. Reisner, M. Cadillac Desert: the American West and its disappearing water, 2nd ed.; Penguin Books: New York, USA, 1993; 582 p.

8. Miller, C. Fluid arguments: five centuries of western water conflict; U. of Arizona Press: Tucson, USA, 2001; 354 p.

9. Powell, J.W. Report on the lands of the arid region of the United States, with a more detailed account of the lands of Utah, U.S. Congress, 45th, 2nd session, House Executive Document 73; Washington DC, USA, 1878; 195 p.

10. Tarlock, A.D. New water transfer restrictions: the West returns to Riparianism. Water Resour. Res. 1991, 27, 978-994.

11. Burness, H.S.; Quirk, J.P. Appropriative water rights and the efficient allocation of resources. Amer. Econ. Rev. 1979, 69, 25-37.

12. Metzger, P.C. Protecting social values in Western water transfers. J. - Am. Water Works. Assoc. 1988, 80, 58-65.

13. Brajer, V.; Martin, W.E. Allocating a 'scarce' resource: water in the West. Am. J. Econ. Soc. 1989, 48, 259-271. 
14. Davis, S.K. The Politics of Water Scarcity in the Western States. Soc. Sci. J. 2001, 38, 527-542.

15. Getches, D. Water law in a nutshell, 3rd ed.; West: St. Paul, USA, 1997; 456 p.

16. Bates, S.F.; Getches, D.H.; MacDonnell, L.J.; Wilkinson, C.F. Searching out the headwaters: change and rediscovery in western water policy; Island Press: Covello, USA, 1993; 242 p.

17. Wilkinson, C.F. Crossing the next meridian: Land, water, and the future of the West; Island Press: Covelo, USA, 1992; 376 p.

18. Fradkin, P. A river no more: the Colorado River and the West; U. of California Press: Berkeley, USA, 1996; $360 \mathrm{p}$.

19. Plummer, J.L. Western water resources: The desert is blooming, but will it continue? Water Resour. Bull. 1994, 30, 595-604.

20. Specter, M. The last drop: confronting the possibility of a global catastrophe. The New Yorker Magazine, 23 October, 2006, 60-71.

21. Worster, D.L. Rivers of empire: water, aridity, and the growth of the American West; Pantheon Books: New York, USA, 1985; 402 p.

22. Wilkinson, C.F. Aldo Leopold and western water law: thinking perpendicular to the prior appropriation doctrine. Land Water Law Rev. 1989, 24, 1-38.

23. Wilkinson, C.F. Western water law in transition. J. - Am. Water Works. Assoc. 1986, 78, 34-47.

24. Gould, G.A. Transfer of water rights. Nat. Resour. J. 1989, 29, 457-477.

25. Wohl, E.E. Virtual Rivers: Lessons from the mountain rivers of the Colorado Front Range; Yale U. Press: New Haven, USA, 2001; 210 p.

26. Wescoat, J.L., Jr. On water conservation and reform of the prior appropriation doctrine in Colorado. Econ. Geog. 1985, 61, 3-24.

27. Perry, T. Imperial Farmers Should Get Less Water, U.S. Report Says. Los Angeles Times, 4 July, 2003, B1.

28. Anderson, T.L.; Leal, D.R. Building coalitions for water marketing. J. Policy Anal. Manag. 1989, 8, 432-445.

29. McNally, M.; Matthews, O.P. Changing the balance in western water law? Montana's reservation system. Nat. Resour. J. 1995, 35, 671-694.

30. Sherk, G.W. East meets West: A tale of two water doctrines. Water Resources Impact, Volume 5, March 2003, pp. 5-8.

31. Colby, B.G. Enhancing instream flow benefits in an era of water marketing. Water Resour. Res. 1990, 26, 1113-1120.

32. Palaniappan, M.; Gleick, P.H.; Hunt, C.; Srinivasan, V. Water privatization principles and practices. In The World's water 2004-2005: the Biennial Report on Freshwater Resources (World's Water); Gleick, P., Eds.; Island Press: Washington DC, USA, 2004; pp. $45-77$.

33. Reisner, M.; Bates, S. Overtapped oasis: reform or revolution for Western water; Island Press: Covelo, USA, 1990; 197 p.

34. Macdonnell, L. Federal Interests in Western Water Resources: Conflict and Accommodation. Nat. Resour. J. 1989, 29, 389-411.

35. Miller, C. Water in the West; Oregon St. U. Press: Corvallis, USA, 2000; 352 p.

36. Tarlock, A.D. Endangered Species Act and Western Water Rights. Land Water Law Rev. 1985, 20, 1-30. 
37. Wescoat, J.L., Jr. Water law, urbanization, and urbanism in the American West: the 'Place of Use' reconsidered. Urban Geogr. 1993, 14, 414-20.

38. Rothman, H.K. Water and the Western service economy: a new challenge. In Fluid arguments: five centuries of western water conflict; Miller, C., Ed.; U of Arizona Press: Tuscon, USA, 2001; pp. 331-338.

39. Brookshire, D.S.; Watts, G.L.; Merrill, J.L. Current issues in the quantification of Federal reserved water rights. Water Resour. Res. 1985, 21, 1777-1784.

40. Feldman, D.L. Preventing the repetition: Or, what Los Angeles' experience in water management can teach Atlanta about urban water disputes. Water Resour. Res. 2009, 45, doi: 10.1029/2008WR007605.

41. Cortese, C.F. The social context of western water development. J. Am. Wat. Resour. Ass. 1999, 35, 567-578.

42. Wescoat, J.L., Jr.; Halvorson, S.; Headington, L.; Replogle, J. Water, poverty, equity and justice in Colorado: a pragmatic approach. In Justice and Natural Resources; Mutz, K.; Bryner, G., Eds.; Island Press: Covelo, USA, 2001; pp. 57-86.

43. Deloria, S. Native American View of Western Water Development. Water Resour. Res. 1985, 21, 1785-1786.

44. Pisani, D.J. The dilemmas of Indian water policy. In Fluid arguments: five centuries of western water conflict; Miller, C., Ed.; U of Arizona Press: Tucson, USA, 2001; pp. 78-94.

45. Western Water Policy Review Advisory Commission. Water in the West: The Challenge for the next century. Technical report; National Technical Information Service: Springfield, USA, 1998; 443 p.

46. U.S. Bureau of Reclamation. Water 2025: Preventing crises and conflict in the West; U.S. Department of the Interior: Washington, DC, USA, 2005; 34 p.

47. Rosegrant, M.W.; Binswanger, H.P. Markets in tradable water rights: Potential for efficiency gains in developing country water resource allocation. World Dev. 1994, 22, 1613-1625.

48. Easter, K.W.; Rosegrant, M.W.; Dinar, A. Formal and informal markets for water: Institutions, performance, and constraints. World Bank Res. Obser. 1999, 14, 99-116.

49. Economist. Priceless. Economist, 17 July, 2003, print edition.

50. Nash, L.L.; Gleick, P.H. The implications of climate change for water resources in the Colorado River Basin. In Proceedings of the 1st national conference on climate change and water resources management, Albuquerque, NM, USA, November 1991; Ballentine, T.M.; Stakhiv, E.Z., Eds.; U.S. Army Corps of Engineers, Water Resources Support Center, Institute for Water Resources: Fort Belvoir, USA, U.S. Army Corps of Engineers, 1993; IWR Report 93-R-17, pp. II: 23-40.

51. Arnell, N.W. Climate change and global water resources. Global Environ. Chang. 1999, 9, S31-S49.

52. Vorosmarty, C.J.; Green, P.; Salisbury, J.; Lammers, R.B. Global water resources: vulnerability from climate change and population growth. Science 2000, 289, 284-288.

53. Gertner, J. The future is drying up: The other water problem. Leadership and Management in Eng. 2008, 8, 139-147.

54. Hanemann, W.M. Valuing the environment through contingent valuation. J. Econ. Perspect. 1994, 8, 19-43. 
55. Ward, F.A.; Michelsen, A.M.; DeMouche, L. Barriers to water conservation in the Rio Grande Basin. J. Am. Wat. Resour. Ass. 2007, 43, 237-253.

56. Lee, T. The water excise tax: preserving a necessary resource. NJLSP 2009, 4, 171-194.

57. Colby, B.G.; d'Estree, T.P. Evaluating market transactions, litigation, and regulations as tools for implementing environmental restoration. Ariz. L. Rev. 2000, 42, 381-394.

58. Hanemann, W.M. The economic conception of water. In Water Crisis: myth or reality?; Rogers, P.; Llamas, M.; Martinez-Cortina, L. Eds.; Taylor and Francis: Leiden, The Netherlands, 2006; pp. 61-91.

59. Saleth, R.M.; Braden, J.B.; Eheart, J.W. Bargaining rules for a thin spot water market. Land Econ. 1991, 67, 326-339.

60. Kenney, D.S. Institutional options for the Colorado River. Water Resour. Bull. 1995, 31, 837-850.

61. Coase, R.H. The problem of social cost. J. Law and Econ. 1960, 3, 1-69.

62. Johansson, R.C.; Tsur, Y.; Roe, T.L.; Doukkali, R.; Dinar, A. Pricing irrigation water: a review of theory and practice. Water Policy 2002, 4, 173-199.

63. Bjornlund, H; McKay, J. Aspects of water markets for developing countries: experiences from Australia, Chile, and the US. Environ. Devel. Econ. 2002, 7, 765-795.

64. Huffman, J.L. Water marketing in western prior appropriation states: a model for the East. Ga. St. U. L. Rev. 2004, 21, 429-448.

65. Hanak, E. Is water policy limiting residential growth? Evidence from California. Land Econ. 2008, 84, 31-50.

66. Hanak, E. Stopping the drain: Third-party responses to California’s water market. Contemp. Econ. Policy 2005, 23, 59-77.

67. Nichols, J. The Milagro Beanfield War; Henry Holt: New York, USA, 1994; 464 p.

68. Dellapenna, J.W. The market alternative. In The Evolution of the Law and Politics of Water; Dellapenna, J.; Gupta, J. Eds.; Springer Netherlands: The Netherlands, 2009; pp. 373-388.

69. Chong, D.; Sunding, D. Water markets and trading. Annu. Rev. Env. Resour. 2006, 31, 239-264.

70. Meinzen-Dick, R. Beyond panaceas in water institutions. Proc. Natl. Acad. Sci. USA 2007, 104, 15200-15205.

71. Megginson, W.L.; Netter, J.M. From state to market: A survey of empirical studies on privatization. J. Econ. Lit. 2001, 39, 321-389.

72. Cummings, R.G.; Nercissiantz, V. The use of water pricing as a means for enhancing water use efficiency in irrigation: Case studies in Mexico and the United States. Nat. Resour. J. 1992, 32, 731-756.

73. Michelsen, A.M. Administrative, institutional, and structural characteristics of an active water market. Water Resour. Bull. 1994, 30, 971-982.

74. Brookshire, D.S.; Colby, B.; Ewers, M.; Ganderton, P.T. Market prices for water in the semiarid West of the United States. Water Resour. Res. 2004, 40, W09S04.

75. Slaughter, R.A.; Wiener, J.D. Water, adaptation, and property rights on the Snake and Klamath Rivers. J. Am. Wat. Resour. Ass. 2007, 43, 308-321.

76. Vaux, H.J.Jr.; Howitt, R.E. Managing water scarcity: An evaluation of interregional transfers. Water Resour. Res. 1984, 20, 785-792. 
77. Knapp, K.C.; Weinberg, M.; Howitt, R.; Posnikoff, J.F. Water transfers, agriculture, and groundwater management: a dynamic economic analysis. J. Environ. Manag. 2003, 67, 291-301.

78. Gosnell, H.; Haggerty, J.H.; Byorth, P.A. Ranch ownership change and new approaches to water resources management in southwestern Montana: Implications for fisheries. J. Am. Wat. Resour. Ass. 2007, 43, 990-1003.

79. Murphy, J.J.; Dinar, A.; Howitt, R.E.; Rassenti, S.J.; Smith, V.L. The design of "smart” water market institutions using laboratory experiments. Envir. Resour. Econ. 2000, 17, 375-394.

80. Booth, T.C. Trends in water market activity and price in the western United States. Water Resour. Res. 2006, 42, W09402.

(C) 2009 by the authors; licensee Molecular Diversity Preservation International, Basel, Switzerland. This article is an open-access article distributed under the terms and conditions of the Creative Commons Attribution license (http://creativecommons.org/licenses/by/3.0/). 